University of Nebraska - Lincoln

DigitalCommons@University of Nebraska - Lincoln

Faculty Papers and Publications in Animal

Science

Animal Science Department

January 1990

TWINNING IN CATTLE: II. GENETIC AND ENVIRONMENTAL

EFFECTS ON OVULATION RATE IN PUBERAL HEIFERS AND

POSTPARTUM COWS AND THE EFFECTS OF OVULATION RATE

ON EMBRYONIC SURVIVAL

\author{
S.E. Echternkamp \\ Roman L. Hruska US Meat Animal Research Center, USDA-ARS, Clay Center, NE \\ K. E. Gregory \\ Roman L. Hruska US Meat Animal Research Center, USDA-ARS, Clay Center, NE \\ G. E. Dickerson \\ Roman L. Hruska US Meat Animal Research Center, USDA-ARS, Clay Center, NE \\ Larry V. Cundiff \\ University of Nebraska-Lincoln, Icundiff2@unl.edu \\ R. M. Koch \\ University of Nebraska-Lincoln, rkoch1@unl.edu \\ See next page for additional authors \\ Follow this and additional works at: https://digitalcommons.unl.edu/animalscifacpub \\ Part of the Animal Sciences Commons
}

Echternkamp, S.E.; Gregory, K. E.; Dickerson, G. E.; Cundiff, Larry V.; Koch, R. M.; and Van Vleck, L. Dale, "TWINNING IN CATTLE: II. GENETIC AND ENVIRONMENTAL EFFECTS ON OVULATION RATE IN PUBERAL HEIFERS AND POSTPARTUM COWS AND THE EFFECTS OF OVULATION RATE ON EMBRYONIC SURVIVAL" (1990). Faculty Papers and Publications in Animal Science. 351.

https://digitalcommons.unl.edu/animalscifacpub/351

This Article is brought to you for free and open access by the Animal Science Department at DigitalCommons@University of Nebraska - Lincoln. It has been accepted for inclusion in Faculty Papers and Publications in Animal Science by an authorized administrator of DigitalCommons@University of Nebraska - Lincoln. 


\section{Authors}

S.E. Echternkamp, K. E. Gregory, G. E. Dickerson, Larry V. Cundiff, R. M. Koch, and L. Dale Van Vleck 


\title{
TWINNING IN CATTLE: II. GENETIC AND ENVIRONMENTAL EFFECTS ON OVULATION RATE IN PUBERAL HEIFERS AND POSTPARTUM COWS AND THE EFFECTS OF OVULATION RATE ON EMBRYONIC SURVIVAL1,2,3
}

\author{
S. E. Echternkamp 4 , K. E. Gregory 4 , G. E. Dickerson ${ }^{4}$, L. V. Cundiff ${ }^{4}$, \\ R. M. Koch ${ }^{5}$ and L. D. Van Vleck ${ }^{4}$
}

U.S. Department of Agriculture ${ }^{6}$, Clay Center, NE 68933

\begin{abstract}
The potential of ovulation rate before 18 to 21 mo of age in puberal heifers as an indirect selection criterion for twinning rate was considered. Heritability $\left(\mathrm{h}^{2}\right)$ was $.07 \pm .03$ for single observations and $.34 \pm .18$ for the mean of 7.9 estrous cycles per heifer. Estimated repeatability ( $r$ ) of ovulation rate was $\mathrm{sh}^{2}$, indicating negligible permanent environmental effects. Expected $h^{2}$ for mean ovulation rate (assuming $h^{2}=r=.07$ for single observations) for increasing numbers of estrous cycles would be as follows: $4, .23$; $6, .31 ; 8, .38$; and $10, .43$. About $50 \%$ of the heifers produced no multiple ovulations, but $27 \%$ produced multiple ovulations in more than $15 \%$ of their estrous cycles. Ovulation rate varied seasonally and increased about .01 per month of age $(P<.05)$. Genetic correlation of mean ovulation rate with adjusted 368 -d weight was low $(.08 \pm .32)$. Ovulation rate in postpartum cows was higher $(P<.05)$ in fall than in spring $(1.15$ vs 1.08$)$. In postpartum cows, estimated $\mathrm{h}^{2}=.24 \pm .13$ and $\mathrm{r}=.17$. Mean ovulation rate for postpartum cows was 1.12 vs 1.09 in puberal heifers, accounting in part for the higher $\mathrm{h}^{2}$. Pregnancy rate was higher $(P<.05)$ in multiple- than in single-ovulating cows. Effects of ovulation rate on embryonic survival were small $(P>.05)$. Unilateral and bilateral multiple ovulations were not different in embryonic survival. Accuracy of ovulation rate determination by palpation per rectum was lower in multiple- than in single-ovulating postpartum cows, because some unilateral multiple corpora lutea, especially, were recorded as singles. Results suggest that use of ovulation rate in puberal heifers should permit effective indirect selection for twinning rate among yearling heifers based on individual performance and among young sires based on ovulation rate of sibs and daughters.

(Key Words: Cattle, Twinning, Heritability, Repeatability, Ovulation, Selection.)
\end{abstract}

J. Anim. Sci. 1990. 68:1877-1888

Introduction

\footnotetext{
${ }^{1}$ Appreciation is expressed to Gordon Hays and Steven Kappes and their staff for the operations support provided to this project. ysis.

${ }^{2}$ Appreciation is expressed to Darrell Light for data anal-

${ }^{3}$ Cooperation of the Nebraska Agric. Exp. Sta. is acknowledged.

${ }^{4}$ Roman L. Hruska U.S. Meat Anim, Res. Center, ARS, USDA, Clay Center, NE 68933.

5 Anim. Sci. Dept., Univ. of Nebraska, Roman L. Hruska U.S. Meat Anim. Res. Center, Clay Center, NE 68933.

${ }^{6}$ Mention of a trade name, proprietary product or specific equipment does not constitute a guarantee or warranty by ARS, USDA and does not imply its approval to the exclusion of other products that may also be suitable.

Received July 27, 1989.

Accepted October 27, 1989.
}

A selection criterion with high predictive value for twinning rate that can be evaluated at a young age is needed for effective selection for twinning rate in cattle. Physical resources generally do not permit retention of all females for several parturitions to observe differences in twinning rate. Further, opportunity for selection among females in cattle is limited because of the relatively high percentage of females required to maintain a constant herd size. Thus, more than $80 \%$ of the selection opportunity for genetic improvement for traits expressed in both sexes of beef cattle is among 
males (Koch et al., 1974). Even if most females could be retained for a number of parturitions to select among females based on individual twinning rate and among sires based on twinning rate of their daughters, progress would be slow because of low heritability and long generation interval. These difficulties might be alleviated by development of a more highly heritable selection criterion observed in young females with high predictive value for twinning rate. Such a criterion would allow effective indirect selection for twinning rate among young females as well as among sires based on a predictor of twinning rate of their sibs and daughters.

Repeated observations of ovulation rate in puberal heifers determined by palpation of corpora lutea per rectum seemed to be a promising approach to explore for indirect selection for twinning rate. The rationale was that ovulation rate in puberal heifers determined over several estrous cycles may be an effective indirect selection criterion for twinning rate (individual performance in females and progeny or sib performance in males) provided that corpora lutea can be palpated with precision, that there is sufficient genetic variation in repeated observations of ovulation rate of puberal heifers and that multiple unilateral and bilateral ovulations do not have a major adverse genetic effect on embryonic survival. Determining ovulation rate in postpartum cows was necessary to estimate the effects of ovulation rate on embryonic survival involving both unilateral and bilateral multiple ovulations.

The objectives of this study were to estimate heritability and repeatability of ovulation rate in puberal heifers and postpartum cows in a population selected intensively for twinning rate, to determine differences in embryonic survival between single and both unilateral and bilateral multiple ovulations and to assess the potential of puberal ovulation rate as an indirect selection criterion for twinning rate.

\section{Materlals and Methods}

The origin of this population, including breeds and their crosses contributing to it and the general management procedures, were presented by Gregory et al. (1990).

Puberal Heifers. Ovulation rate was determined per rectum on 444 single and twin-bom females for 3,516 estrous cycles (a mean of 7.9 per female, Table 1). Females were born in five birth (year-season) groups and were the progeny of 46 sires. Dams ranged in age from 2 to 12 yr. Observations were made in all calendar months. Data collection began when females were approximately 11 mo of age and continued for 6 to $8 \mathrm{mo}$. Observations per female ranged from 1 to 14 . Generally, palpation of spring-born females began in early March and continued until late September, for fall-bom females, palpation began in August and continued until April.

Starting at puberty, approximately one-half of the females bom in the project in fall of 1984 and spring and fall of 1985 by each sire were chosen randomly to be palpated per rectum to determine ovulation rate for 8 to 10 estrous cycles and to be exposed first for breeding at approximately 18 to 21 mo of age to produce their first calves at about 2.5 yr of age. Half-sib contemporaries not palpated were exposed to breeding at 12 to 15 mo of age and produced their first calves at approximately 2 yr of age. Some heifers born in the spring of 1986 contributed to another experiment and did not provide data useful for this analysis. Because ovulation rate was determined on the remaining nonrandom sample of heifers for an average of only 3.7 estrous cycles, data from the spring 1986 birth group were deleted from the analysis (Table 1).

Results from a preliminary analysis of data supported a decision to determine ovulation rate on all heifers, starting with those bom in the fall of 1986. Thus, all heifers born in the fall of 1986 and the spring of 1987 were palpated per rectum to determine ovulation rate for 8 to 10 estrous cycles and were exposed first for breeding at an age of 18 to 21 mo to produce their first calves at an age of approximately $2.5 \mathrm{yr}$.

Postpartum Cows. Ovulation rate and subsequent embryonic survival were determined for a sample of cows in 1985, 1986 and 1987. Postpartum cows in the experiment were artificially inseminated $12 \mathrm{~h}$ postestrus for a 40-d period followed by natural service for about $20 \mathrm{~d}$ in individual sire pastures during both spring and fall breeding seasons. In 1985, a random sample of postpartum cows ( $n=102$ in spring and 113 in fall) were laparoscoped 7 to $11 \mathrm{~d}$ after artificial insemination to determine ovulation rate and to allow evaluation of the effects of ovulation rate on conception rate 
TABLE 1. ESTIMATES OF GENETIC AND ENVIRONMENTAL EFFECTS ON OVULATION RATE OF PUBERAL FEMALES

\begin{tabular}{|c|c|c|}
\hline Item & $\begin{array}{l}\text { All } \\
\text { data }\end{array}$ & $\begin{array}{l}\text { Minus daughters of } \\
\text { embryo-transfer dams } \\
\text { and of progeny- } \\
\text { tested sires }\end{array}$ \\
\hline $\begin{array}{l}\text { No. of sires } \\
\text { No. of females } \\
\text { No. of observations } \\
\text { Mean observations/female }\end{array}$ & $\begin{array}{r}46 \\
444 \\
3,516 \\
7.9\end{array}$ & $\begin{array}{c}40 \\
306 \\
2,421 \\
7.9\end{array}$ \\
\hline $\begin{array}{l}\text { Analysis of variance } \\
\text { Sires }(S) \\
\text { Daughters/S } \\
\text { Birth group } \\
\text { Month of observation } \\
\text { Age-months } b_{1} \text {-linear }\end{array}$ & $\begin{array}{l}* * \\
* * \\
* * \\
* * \\
* *\end{array}$ & $\begin{array}{l}* * \\
* * \\
N^{*} \\
*\end{array}$ \\
\hline $\begin{array}{l}\text { Least squares means } \\
\text { Mean }\end{array}$ & 1.12 & 1.09 \\
\hline $\begin{array}{l}\text { Birth group } \\
1984 \text { Fall } \\
1985 \text { Spring } \\
1985 \text { Fall } \\
1986 \text { Fall } \\
1987 \text { Spring }\end{array}$ & $\begin{array}{l}1.12 \\
1.06 \\
1.12 \\
1.14 \\
1.15\end{array}$ & $\begin{array}{l}1.10 \\
1.12 \\
1.07 \\
1.09 \\
1.10\end{array}$ \\
\hline $\begin{array}{l}\text { Month of observation } \\
1 \\
2 \\
3 \\
4 \\
5 \\
6 \\
7 \\
8 \\
9 \\
10 \\
11 \\
12\end{array}$ & $\begin{array}{l}1.12 \\
1.11 \\
1.06 \\
1.12 \\
1.10 \\
1.18 \\
1.10 \\
1.10 \\
1.12 \\
1.12 \\
1.18 \\
1.12\end{array}$ & $\begin{array}{l}1.10 \\
1.10 \\
1.04 \\
1.08 \\
1.04 \\
1.12 \\
1.10 \\
1.08 \\
1.09 \\
1.11 \\
1.15 \\
1.13\end{array}$ \\
\hline $\begin{array}{l}\text { Age-months, linear regression } \\
\text { Estimates of heritability } \mathrm{h}^{2} \text { and repeat }\end{array}$ & .009 & .009 \\
\hline $\begin{array}{l}\text { Model } 1 \\
h^{2} \text { excluding birth group } \\
\mathrm{r} \text { excluding birth group } \\
\mathrm{h}^{2} \text { analysis by birth group-pooled } \\
\mathrm{r} \text { analysis by birth group-pooled }\end{array}$ & $\begin{array}{l}.15 \pm .04 \\
.10 \\
.17 \\
.09\end{array}$ & $\begin{array}{l}.07 \pm .03 \\
.05\end{array}$ \\
\hline $\begin{array}{l}\text { Model } 2 \\
\text { r excluding birth group } \\
\text { I analysis by birth group-pooled }\end{array}$ & .10 & .04 \\
\hline
\end{tabular}

Eixed effects were computed from a model that deleted daughters within sires as a random effect.

bS = not significant.

$* P \leq .05$.

$* * P \leq .01$.

and embryonic loss. In the spring and fall of both 1986 and 1987, ovulation rate was determined by rectal palpation of the ovaries 6 to $10 \mathrm{~d}$ after insemination in all postpartum cows bred during approximately the first $30 \mathrm{~d}$ of each breeding season. Thus, results are based on observations made by laparoscopy in 1985 and by rectal palpation in 1986 and 1987.
Differences between ovulation rate and calving rate to each insemination were attributed to embryonic loss.

Laparoscopic and Rectal Palpation Procedures. Visualization of both the right and left ovary was accomplished using a laparoscope $60 \mathrm{~cm}$ in length and $10 \mathrm{~mm}$ in diameter and containing a fiber optical light source. ${ }^{7}$ The 
right paralumbar fossa was shaved, scrubbed and sterilized. A 2- to $3-\mathrm{cm}$ incision was made in the skin approximately $30 \mathrm{~cm}$ below the hip bone after the incision site and underlying musculature had been anesthetized with $2 \%$ procaine solution. A pyramidal trocar, $10 \mathrm{~mm}$ in diameter and $22 \mathrm{~cm}$ in length, and trocar sleeve were inserted into the incision and forced through the musculature and fascia and into the peritoneal cavity. The trocar was withdrawn from the sleeve and the laparoscope was inserted in the peritoneal cavity via the trocar sleeve. The peritoneal cavity was insufflated with $\mathrm{CO}_{2}$ to aid visualization of the ovaries. A second incision into the skin was made approximately $10 \mathrm{~cm}$ below the first incision and a smaller trocar and sleeve $(6 \mathrm{~mm}$ in diameter, $17 \mathrm{~cm}$ long) was inserted into the peritoneal cavity. The trocar was removed and a 75-cm stainless steel probe was inserted. The probe was utilized for manipulation of the ovaries to enable visualization of the entire ovarian surface. Number and size of follicles and corpora lutea on the surface of each ovary were recorded, as well as any abnormalities of the reproductive tract. After removal of the laparoscope, $500 \mathrm{ml}$ of saline (containing 4.4 $\mathrm{mg}$ ampicillin per $\mathrm{kg} \mathrm{BW}$ ) was infused into the peritoneal cavity via the laparoscope sleeve. Both sleeves were removed, the two skin incisions were closed with a single suture each and a topical antiseptic was applied to the incision sites.

All determinations of ovulation rate by rectal palpation were performed by one person proficient in the technique. In 1986 and 1987, each postpartum cow having two corpora lutea as determined by rectal palpation was paired with a cohort having a single ovulation; both were laparoscoped to evaluate the precision of determining ovulation rate by rectal palpation.

\section{Analysis of Data}

Puberal Heifers. Data were analyzed using least squares mixed model procedures (Harvey, 1977). Some of the females were produced by embryo transfer from dams and sires thought to be genetically superior for twinning, others were by sires selected on twinning rate of their daughters and some involved both of these situations. Hence, two data sets were analyzed.

\footnotetext{
II.

${ }^{7}$ Richard Wolf Medical Instruments Corp., Rosemont,
}

The smaller set was a subset of the other.

The fixed effects presented in Table 1 were estimated from a model that included sires, but deleted daughters within sires, as a random effect. Age in months $\left(b_{1}\right.$-linear) was included in the model as a covariate; the quadratic coefficient was not significant. A preliminary analysis indicated no significant effects of age of dam, type of birth (single vs twin), or interactions among fixed effects. These variables were deleted from the model for the final analysis. The model used to estimate genetic parameters included sires and daughters within sires as random effects, with the fixed effects indicated in Table 1.

Because the fixed effects of birth group do not vary across repeated records of each siredaughter unit, the fixed effects of birth group could not be included in a model that included daughters within sires as a random effect. In analyses that included all data, one analysis deleted birth group and another was conducted separately for each birth group, pooling variance components across birth groups to estimate heritability and repeatability (Table 1).

Postpartum Cows. Least squares mixed model procedures for analysis of postpartum data were used in a model that included sires and cows within sires as random effects and season, year and age of cow as fixed effects (Harvey, 1977). Even though the effects of year and age of cow were not significant, year was kept in the model because of the different procedures used to determine ovulation rate in 1985 and 1986-1987 and because ovulation rates for different ages of cows are of interest.

Because of the diversity of questions addressed and specificity of analytical procedures used to address each question, statistical methods used for data analysis are described further in Results and Discussion.

\section{Results and Discussion}

Results from analyses of data sets that include all data (i.e., progeny of selected sires) are reported because they reflect to some degree the potential of selection for the traits involved compared with results from analysis of the data where selection intensity was less.

\section{Heritability and Repeatability of Ovulation Rate}

Puberal Heifers. Effects of birth group were significant only in the data set that included all 
data. Month of observation and regression of ovulation rate on age (months) were significant in both data sets (Table 1). Ovulation rates were 1.09 and 1.12 in the two data sets (Table 1). In the data set that included all data, ovulation rate in the right ovary averaged .63 ova and in the left ovary averaged .48 ova. Ovulation rate was highest $(P<.05)$ in the months of June and November in both data sets.

The effects of sires $\left(1 / 4 \sigma_{g}^{2}\right)$ and of daughters within sires $\left(3 / 4 \sigma_{g}^{2}+\sigma_{p e}^{2}\right)$ were significant in the analysis of both data sets, where $\sigma_{\mathrm{g}}^{2}=$ genetic variance and $\sigma_{\mathrm{pe}}^{2}=$ variance due to permanent environmental effects. Estimates of heritability for single observations varied between the data sets as expected (Table 1). The estimate obtained from the analysis of all data is subject to upward bias from two sources, i.e., the dams used for embryo transfer were mated to sires thought to be superior genetically for twinning rate, and some of the heifers also were by sires chosen for known superiority of daughters' twinning rate. If mated to a random sample of sires, the superiority of the dams used for embryo transfer would tend to inflate the estimate of the variance component for daughters within sires $\left(3 / 4 \sigma_{g}^{2}+\sigma_{p e}^{2}\right)$ and thus cause underestimation of the sire component.

The estimate of heritability for ovulation rate including all data was not greatly affected by whether or not birth group was considered; i.e., .15 when birth group was not considered and .17 when separate analyses were conducted for each birth group and heritability was estimated from the pooled variance components estimated for each birth group (Table 1). Because the effects of birth group were not significant in the data set that excluded heifers produced by embryo transfer and heifers by progeny-tested sires, heritability estimated from pooling variance components of birth groups is not reported. Heritability of $.07 \pm .03$ for ovulation rate from the data set that excluded both daughters of embryotransfer dams and daughters of progeny-tested sires should be less subject to bias due to selection for twinning rate (Table 1).

Repeatability of ovulation rate was estimated from two models in both data sets. Model 1 included sires $\left(1 / 4 \sigma_{g}^{2}\right)$ and daughters within sires $\left(3 / 4 \sigma_{g}^{2}+\sigma_{p e}^{2}\right)$ as random effects and the fixed effects indicated in Table 1. Model 2 included heifers $\left(\sigma_{g}^{2}+\sigma_{p e}^{2}\right)$ as a random effect and the fixed effects indicated in Table 1. Estimates of repeatability were smaller than the estimates of heritability. In Model 1 estimates of variance components for daughters within sires (expectation of $3 / 4 \sigma_{g}^{2}+$ $\sigma_{p e}^{2}$ ) were less than expected, i.e., less than three times the sire component of variance (expectation of $1 / 4 \sigma_{\mathrm{g}}^{2}$, with no contribution from permanent environmental effects). Thus, we conciude that permanent environmental effects on ovulation rate of puberal heifers are probably of little importance.

For the complete data set, estimates of repeatability were essentially the same from Model 1 and Model 2; i.e., .10 when birth group was excluded from the model and .09 when repeatability was estimated from pooled estimates of variance components for each birth group (Table 1).

A covariance analysis of mean ovulation rate for each female (mean $n=7.9$ observations per female) and adjusted 368-d weight was conducted for both data sets. This model included sires $\left(1 / 4 \sigma_{g}^{2}\right)$ as a random effect and birth group as a fixed effect. Estimates were obtained for heritability of mean ovulation rate and adjusted 368-d weight and of the genetic, phenotypic and environmental correlations between these two traits (Table 2). These estimates include effects of differences in breed composition for both traits. Breed effects on 368-d weight probably are greater than on ovulation rate in this data set.

In the analysis that excluded both daughters of embryo-transfer dams and daughters of progeny-tested sires, heritability of mean ovulation rate and adjusted 368-d weight were, respectively, $.34 \pm .18$ and $.80 \pm .24$. Estimates of genetic, phenotypic and environmental correlations were, respectively $.08 \pm .32, .15$ and .28 (Table 2). The estimates of heritability and genetic correlation obtained from all data reflect the upward bias in estimates of the sire component of variance from mating selected sires to selected embryo-transfer dams.

Average number of progeny per sire was 7.6 and observations per female averaged 7.9. An estimate of heritability from single cycle data (i.e., .07) and the assumption of no 
TABLE 2. ESTIMATES OF HERITABILITY AND GENETIC (rg), PHENOTYPIC (rp) AND ENVIRONMENTAL (re) CORRELATIONS FOR MEAN OVULATION RATE AND ADJUSTED 368-DAY WEIGHT

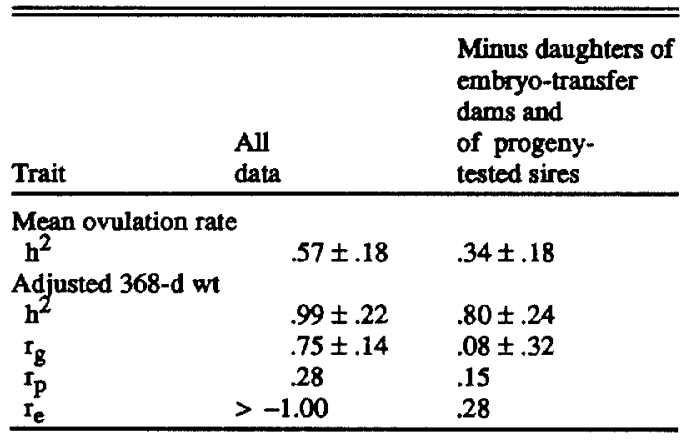

permanent environmental effects on ovulation rate (i.e., repeatability $=.07$ ) were used to estimate heritability of mean ovulation rate based on $4,5,6,7,8,9$ and 10 observations of ovulation rate per puberal female, using the equation of Lush (1945) $h_{x}^{2-}=n h^{2} / 11+(n-$ 1) $r$ ] ( $\mathrm{n}=$ number of observations, $r=$ repeatability). Based on these assumptions, estimates of heritability of mean ovulation rate for increasing numbers of single cycle data were $4, .23 ; 5, .27 ; 6, .31 ; 7, .34 ; 8, .38 ; 9, .40$; and $10, .43$. These estimates are in general agreement with the estimate of heritability (.34) for mean ovulation rate for 7.9 estrous cycles obtained from analysis of the unbiased data and suggest that measuring ovulation rate of puberal females for 8 to 10 estrous cycles should be effective in selecting for ovulation rate and indirectly for twinning rate assuming a high positive genetic correlation between ovulation rate and twinning rate.

The frequency distribution of mean ovulation rate in puberal heifers is presented in Table 3. About one-half $(49.8 \%)$ of the 444 females observed produced no multiple ovulations when this class was observed for a mean of 6.8 estrous cycles. Because the heifers that produced no multiple ovulations had only 1.1 fewer observations per heifer than the mean for all 444 heifers observed, their failure to produce multiple ovulations cannot be attributed to fewer observations.

Ovulation rate among puberal heifers followed a one-tail Poisson distribution, with no suggestion of bimodality as would be expected for a segregating gene with a major effect. The same conclusion was indicated for twinning rate (Gregory et al., 1990).
Postpartum Cows. Observations used in this analysis (Table 4) were made only by laparoscopy in 1985 and only by palpation per rectum in 1986 and 1987. Observations totaled 1,065 on 505 females by 49 sires of females bom in the project; i.e., foundation cows were excluded. When daughters of embryo-transfer dams and daughters of progeny-tested sires were both excluded from the data set, observations totaled 741 on 352 females by 43 sires.

Multiple ovulations were observed at almost twice the frequency $(P<.01)$ in the fall $(.15)$ as in the spring (.08). These frequencies are consistent with differences in twinning rate observed between fall and spring calving (Gregory et al., 1990).

The effects of sire $\left(1 / 4 \sigma_{\mathrm{g}}^{2}\right)$ and cow within sire $\left(3 / 4 \sigma_{\mathrm{g}}^{2}+\sigma_{\mathrm{pe}}^{2}\right)$ were significant in both data sets. The estimates of heritability for single observations of ovulation rate in postpartum cows were $.25 \pm .11$ and $.24 \pm .13$ for the two data sets (Table 4). These estimates of heritability for ovulation rate in postpartum cows are higher than those for puberal heifers reported earlier in this paper. Mean ovulation rate was only slightly greater in postpartum cows than in puberal heifers (12 vs $9 \%$ ).

Repeatability was estimated from variance components calculated from two models. Model 1 included sires $\left(1 / 4 \sigma_{\mathrm{g}}^{2}\right)$ and cows within sire $\left(3 / 4 \sigma_{\mathrm{g}}^{2}+\sigma_{\mathrm{pe}}^{2}\right)$ as random effects, and Model 2 included only cows $\left(\sigma_{\mathrm{g}}^{2}+\sigma_{\mathrm{pe}}^{2}\right)$ as a random effect. Estimates of repeatability did not differ between the two models. The lower than expected estimate of repeatability (.16 to $.20)$ relative to heritability $(.25$ and .24$)$ in both models may arise from a low negative environmental correlation between number of ovulations in successive estrous cycles, which would reduce the component of variance for cow within sire $\left(3 / 4 \sigma_{\mathrm{g}}^{2}+\sigma_{\mathrm{pe}}^{2}\right)$ relative to that for sires $\left(1 / 4 \sigma_{g}^{2}\right)$.

Effects of Ovulation Rate on Conception and on Embryonic and Fetal Survival in Postpartum Cows

Results from analyses of the effects of ovulation rate on conception rate and embryonic survival are presented in Table 5. Data for this part of the study were obtained from 
TABLE 3. FREQUENCY DISTRIBUTION OF MULTIPLE OVULATIONS IN PUBERTAL FEMALES ${ }^{a}$

\begin{tabular}{|c|c|c|c|c|c|c|}
\hline $\begin{array}{l}\text { Mean } \\
\text { ovulation } \\
\text { rate }\end{array}$ & $\begin{array}{l}\text { No. of } \\
\text { females }\end{array}$ & $\begin{array}{l}\text { No. of } \\
\text { observations/ } \\
\text { female }\end{array}$ & $\begin{array}{l}\text { No. of } \\
\text { multiple } \\
\text { ovulations/ } \\
\text { female }\end{array}$ & $\begin{array}{l}\text { Mean } \\
\text { ovulation } \\
\text { rate }\end{array}$ & $\begin{array}{l}\text { No. of } \\
\text { females }\end{array}$ & $\begin{array}{l}\text { Percentage } \\
\text { of total }\end{array}$ \\
\hline 1.00 & 221 & $1-14$ & 0 & 1.00 & 221 & 49.8 \\
\hline $\begin{array}{l}1.08 \\
1.08 \\
1.09 \\
1.10 \\
1.11 \\
1.12\end{array}$ & $\begin{array}{r}5 \\
11 \\
6 \\
14 \\
34 \\
23\end{array}$ & $\begin{array}{l}13 \\
12 \\
11 \\
10 \\
9 \\
8\end{array}$ & $\begin{array}{l}1 \\
1 \\
1 \\
1 \\
1 \\
1\end{array}$ & 190 & & \\
\hline 1.14 & 10 & 7 & 1 & $1.00-1.15$ & 103 & 23.2 \\
\hline $\begin{array}{l}1.15 \\
1.17 \\
1.18 \\
1.20 \\
1.22 \\
1.23 \\
1.25 \\
1.27 \\
1.28 \\
1.30\end{array}$ & $\begin{array}{r}4 \\
3 \\
5 \\
14 \\
16 \\
1 \\
17 \\
4 \\
4 \\
4\end{array}$ & $\begin{array}{l}13 \\
6 \\
11 \\
5,10 \\
9 \\
13 \\
4,8,12 \\
11 \\
7 \\
10\end{array}$ & $\begin{array}{l}2 \\
1 \\
2 \\
1,2 \\
2 \\
3 \\
1,2,3 \\
3 \\
2 \\
3\end{array}$ & $15-130$ & 72 & 162 \\
\hline $\begin{array}{l}1.33 \\
1.36 \\
1.38 \\
1.40 \\
1.42 \\
1.44\end{array}$ & $\begin{array}{r}15 \\
2 \\
4 \\
3 \\
2 \\
4\end{array}$ & $\begin{array}{l}3,6,9,12 \\
11 \\
8 \\
10 \\
12 \\
9\end{array}$ & $\begin{array}{l}1,2,3,4 \\
4 \\
3 \\
4 \\
5 \\
4\end{array}$ & $1.30-1.45$ & 30 & 6.8 \\
\hline $\begin{array}{l}1.45 \\
1.50 \\
1.54 \\
1.58 \\
1.60\end{array}$ & $\begin{array}{l}1 \\
7 \\
1 \\
1 \\
1\end{array}$ & $\begin{array}{l}11 \\
2,6,8,10,12 \\
11 \\
12 \\
10\end{array}$ & $\begin{array}{l}5 \\
1,3,4,5,6 \\
6 \\
7 \\
6\end{array}$ & $1.45-1.60$ & 11 & 2.5 \\
\hline $\begin{array}{l}1.67 \\
1.70 \\
1.75 \\
1.78\end{array}$ & $\begin{array}{l}2 \\
1 \\
3 \\
1\end{array}$ & $\begin{array}{l}3,9 \\
10 \\
8 \\
9\end{array}$ & $\begin{array}{l}2,6 \\
7 \\
6 \\
7\end{array}$ & $1.60-1.78$ & 7 & 1.6 \\
\hline
\end{tabular}

${ }^{2}$ Mean ovulation rate per estrous cycle $=1.12$ and mean number observations per female $=7.9$.

foundation cows and from cows bom in the project. Because ovulation rate was determined only by laparoscopy in 1985 and by both laparoscopy and palpation in 1986 and 1987 , the laparoscopy and palpation data were analyzed separately. Cows laparoscoped in 1986 and 1987 are included in both data sets with the values used in each data set consistent with the procedure used to obtain them. Each insemination was an observation for pregnancy rate based on parturition and each ovulation site was an observation for embryonic and fetal survival. Calving rate was used to evaluate the effects of ovulation rate on embryonic and fetal survival.

The model included the fixed effects of year, season of breeding (spring or fall), ovulation number (single or multiple), ovula- tion site (right ovary or left ovary both for single and for multiple ovulations) and all possible interactions. Age (years) of cow $\left(b_{1-}\right.$ linear and $b_{2}$-quadratic) was included in the model as a covariate.

The data set collected by palpation of corpora lutea included 867 observations on postpartum cows that varied in age from 2 through $9 \mathrm{yr}$. The data set collected by laparoscopy included 474 observations on postpartum cows of the same age distribution.

Conception Rate. The effects of season of breeding (spring or fall) and ovulation number (single or multiple) on conception rate were statistically significant in the data obtained by palpation but not in the data obtained by laparoscopy (Table 5). However, the differences for both season and ovulation number 
TABLE 4. GENETIC AND ENVIRONMENTAL EFFECTS ON OVULATION RATE IN POSTPARTUM COWS BORN IN PROJECT

\begin{tabular}{|c|c|c|c|c|}
\hline \multirow[b]{2}{*}{ Item } & \multicolumn{2}{|c|}{ All data } & \multicolumn{2}{|c|}{$\begin{array}{l}\text { Minus daughters of } \\
\text { embryo-transfer dams } \\
\text { and of progeny- } \\
\text { tested sires }\end{array}$} \\
\hline & df & Significance & df & Significance \\
\hline \multicolumn{5}{|c|}{ Analysis of variance } \\
\hline Sires (S) & 48 & $* *$ & 42 & $* *$ \\
\hline Cow/S & 456 & $* *$ & 309 & ** \\
\hline Season & 1 & $* *$ & 1 & ** \\
\hline Year & 2 & $\mathbf{N S}^{\mathbf{a}}$ & 2 & NS \\
\hline Age of cow & 3 & NS & 3 & NS \\
\hline \multicolumn{5}{|c|}{ Least squares means } \\
\hline Mean & 1065 & 1.13 & 741 & 1.12 \\
\hline \multicolumn{5}{|c|}{ Season of breeding } \\
\hline Spring & 599 & 1.08 & 395 & 1.08 \\
\hline Fall & 466 & 1.18 & 346 & 1.15 \\
\hline \multicolumn{5}{|l|}{ Year of record } \\
\hline 1985 & 117 & 1.11 & 100 & 1.11 \\
\hline 1986 & 363 & 1.13 & 268 & 1.10 \\
\hline 1987 & 585 & 1.15 & 373 & 1.14 \\
\hline \multicolumn{5}{|l|}{ Age of cow } \\
\hline $2 \mathrm{yr}$ & 449 & 1.14 & 284 & 1.10 \\
\hline $3 \mathrm{yr}$ & 326 & 1.10 & 223 & 1.09 \\
\hline $4 y r$ & 155 & 1.13 & 106 & 1.13 \\
\hline $5+y \mathrm{r}$ & 135 & 1.16 & 128 & 1.14 \\
\hline \multicolumn{5}{|c|}{ Estimates of heritability $h^{2}$ and repeatability (r) } \\
\hline$h^{2}$ & & $.25 \pm .11$ & & $.24 \pm .13$ \\
\hline $\mathbf{r}$ & Model $1^{b}$ & .20 & & $.17+.10$ \\
\hline $\mathbf{r}$ & Model $2^{b}$ & .20 & & .16 \\
\hline
\end{tabular}

were similar in both data sets. Year $\times$ season of breeding interaction was significant in the data set obtained by palpation but not in the data set obtained by laparoscopy, whereas the interaction of year $x$ ovulation number was significant in the data set obtained by laparoscopy but not by palpation. The quadratic regression of conception rate on age of cow was significant in both data sets. Conception rate decreased as age increased beyond $5 \mathrm{yr}$. The significant effect of season of breeding and the interaction of year $x$ season of breeding in the data set obtained by palpation is the result of an extremely high conception rate (.82) observed in the spring of 1986 and a smaller than average conception rate (.62) observed in the fall of 1986. A less than normal level of husbandry during the fall of 1986 breeding season may account for this lower than average conception rate. The significant year $\times$ ovulation number interaction in the data obtained by laparoscopy is due to a higher conception rate in single- than in multiple-ovulating cows in 1986, whereas conception rate was higher in multiple ovulating cows in the two other years. Because conception rate is computed on the basis of parturition rate per cow inseminated, a higher conception rate is expected in cows ovulating multiple oocytes than in cows ovulating a single oocyte. An increase in conception rate also was reported for cows induced to multiple ovulate with gonadotropin treatment (Gordon et al., 1962).

Embryonic and Fetal Survival. The effects of season of breeding, the interaction of year $x$ season and the quadratic regression on age of cow were significant for embryonic survival in the data set obtained by palpation. Embryonic survival was greater in the spring than in the fall. This difference between spring and fall breeding and the interaction of year $\times$ season of breeding is accounted for largely by the lower embryonic survival in the fall of 1986 relative to the high embryonic and fetal survival observed for the spring of 1986. 
TABLE 5. EFFECTS OF OVULATION RATE ON CONCEPTION RATE AND EMBRYONIC SURVIVAL IN POSTPARTUM COWS INCLUDING FOUNDATION COWS AND COWS BORN IN PROJECT

\begin{tabular}{|c|c|c|c|c|c|c|c|c|}
\hline \multirow[b]{2}{*}{ Item } & \multicolumn{4}{|c|}{ Conception rate } & \multicolumn{4}{|c|}{ Embryonic and fetal survival } \\
\hline & No. & Palpation & No. & Laparoscope & No. & Palpation & No. & Laparoscope \\
\hline $\begin{array}{l}\text { Analysis of variance } \\
\text { Year }(\mathbf{Y}) \\
\text { Season }(S) \\
\text { Ovulation rate }(O) \\
\text { Ovulation site } \\
\text { single } \\
\text { multiple } \\
Y \times O \\
Y \times S \\
\text { Age-linear regression } \\
\text { Quadratic regression }\end{array}$ & & $\begin{array}{l}N^{2} \\
* * \\
\text { NS } \\
\text { NS } \\
\text { NS } \\
\text { NS } \\
+*\end{array}$ & & $\begin{array}{l}\text { NS } \\
\text { NS } \\
\text { NS } \\
\text { NS } \\
\text { NS } \\
* \\
\text { NS } \\
\text { NS } \\
* *\end{array}$ & & $\begin{array}{l}\text { NS } \\
* * \\
\text { NS } \\
\text { NS } \\
\text { NS } \\
\text { NS } \\
* * \\
\text { NS } \\
* *\end{array}$ & & $\begin{array}{l}* \\
\text { NS } \\
\text { NS } \\
\text { NS } \\
\text { NS } \\
\text { * } \\
\text { NS } \\
\text { NS } \\
*\end{array}$ \\
\hline $\begin{array}{l}\text { Least squares means } \\
\text { Mean }\end{array}$ & 867 & .71 & 474 & .73 & 867 & .63 & 474 & .65 \\
\hline $\begin{array}{l}\text { Year } \\
1985 \\
1986 \\
1987\end{array}$ & $\begin{array}{l}428 \\
439\end{array}$ & $\begin{array}{l}.72 \\
.70\end{array}$ & $\begin{array}{l}213 \\
110 \\
151\end{array}$ & $\begin{array}{l}.79 \\
.75 \\
.66\end{array}$ & $\begin{array}{l}428 \\
439\end{array}$ & $\begin{array}{l}.64 \\
.62\end{array}$ & $\begin{array}{l}213 \\
110 \\
151\end{array}$ & $\begin{array}{l}.71 \\
.68 \\
.56\end{array}$ \\
\hline $\begin{array}{l}\text { Season } \\
\text { Spring } \\
\text { Fall }\end{array}$ & $\begin{array}{l}369 \\
498\end{array}$ & $\begin{array}{l}.77 \\
.65\end{array}$ & $\begin{array}{l}192 \\
282\end{array}$ & $\begin{array}{l}.76 \\
.70\end{array}$ & $\begin{array}{l}369 \\
498\end{array}$ & $\begin{array}{l}.68 \\
.57\end{array}$ & $\begin{array}{l}192 \\
282\end{array}$ & $\begin{array}{l}.67 \\
.63\end{array}$ \\
\hline $\begin{array}{l}\text { Ovulation rate } \\
\text { Single } \\
\text { Multiple }\end{array}$ & $\begin{array}{l}726 \\
141\end{array}$ & $\begin{array}{l}.67 \\
.75\end{array}$ & $\begin{array}{l}319 \\
155\end{array}$ & $\begin{array}{l}.69 \\
.77\end{array}$ & $\begin{array}{l}726 \\
141\end{array}$ & $\begin{array}{l}.66 \\
.60\end{array}$ & $\begin{array}{l}319 \\
155\end{array}$ & $\begin{array}{l}.68 \\
.62\end{array}$ \\
\hline $\begin{array}{l}\text { Ovulation site } \\
\text { Single }\end{array}$ & & & & & & & & \\
\hline $\begin{array}{l}\mathbf{R} \\
\mathbf{L} \\
\text { Multiple }\end{array}$ & $\begin{array}{l}437 \\
289\end{array}$ & $\begin{array}{l}.65 \\
.68\end{array}$ & $\begin{array}{l}205 \\
114\end{array}$ & $\begin{array}{l}.69 \\
.69\end{array}$ & $\begin{array}{l}437 \\
289\end{array}$ & $\begin{array}{l}.64 \\
.68\end{array}$ & $\begin{array}{l}205 \\
114\end{array}$ & $\begin{array}{l}.68 \\
.68\end{array}$ \\
\hline $\begin{array}{l}\mathbf{R} \\
\mathbf{L} \\
\mathbf{B}\end{array}$ & $\begin{array}{l}47 \\
39 \\
55\end{array}$ & $\begin{array}{l}.72 \\
.81 \\
.74\end{array}$ & $\begin{array}{l}57 \\
35 \\
63\end{array}$ & $\begin{array}{l}.69 \\
.81 \\
.81\end{array}$ & $\begin{array}{l}47 \\
39 \\
55\end{array}$ & $\begin{array}{l}.59 \\
.63 \\
.57\end{array}$ & $\begin{array}{l}57 \\
35 \\
63\end{array}$ & $\begin{array}{l}.56 \\
.67 \\
.62\end{array}$ \\
\hline Interactions $^{c}$ & $\mathbf{Y} \times \mathbf{S}$ & & $\mathbf{Y} \times \mathbf{O}$ & & $\mathbf{Y} \times \mathbf{S}$ & & $\mathbf{Y} \times \mathbf{O}$ & \\
\hline 1985 & & & $\begin{array}{l}\text { (1) } 184 \\
\text { (2) } 29\end{array}$ & $\begin{array}{l}.69 \\
.89\end{array}$ & & & $\begin{array}{l}\text { (1) } 184 \\
\text { (2) } 29\end{array}$ & $\begin{array}{l}.68 \\
.74\end{array}$ \\
\hline $\begin{array}{l}1986 \\
1987\end{array}$ & $\begin{array}{l}\text { (S) } 200 \\
\text { (F) } 228 \\
\text { (S) } 169 \\
\text { (F) } 270\end{array}$ & $\begin{array}{l}.82 \\
.62 \\
.71 \\
.68\end{array}$ & $\begin{array}{l}\text { (1) } 64 \\
\text { (2) } 46 \\
\text { (1) } 71 \\
\text { (2) } 80\end{array}$ & $\begin{array}{l}.82 \\
.68 \\
.57 \\
.74\end{array}$ & $\begin{array}{l}\text { (S) } 200 \\
\text { (F) } 228 \\
\text { (S) } 169 \\
\text { (F) } 270\end{array}$ & $\begin{array}{l}.73 \\
.54 \\
.63 \\
.60\end{array}$ & $\begin{array}{l}\text { (1) } 64 \\
\text { (2) } 46 \\
\text { (1) } 71 \\
\text { (2) } 80\end{array}$ & $\begin{array}{l}.81 \\
.55 \\
.56 \\
.56\end{array}$ \\
\hline $\begin{array}{l}\text { Age, yr } \\
\text { Linear regression } \\
\text { Quadratic regression }\end{array}$ & & $\begin{array}{r}.01 \\
-.03\end{array}$ & & $\begin{array}{l}-.00 \\
-.03\end{array}$ & & $\begin{array}{r}.00 \\
-.03\end{array}$ & & $\begin{array}{l}-.01 \\
-.03\end{array}$ \\
\hline
\end{tabular}

NS = not significant.

${ }^{b} R$, right ovary; L, left oyary; B, bilateral.

${ }^{\prime}(S)$, spring; (F), fall; (1), single ovulation; (2), multiple ovulation.

$* P \leq .05$.

$* * P \leq .01$.

Again, the lower embryonic and fetal survival is attributed to a lower level of husbandry during the fall of 1986 breeding season. Although embryonic and fetal survival was less in fall-bred than in spring-bred cows, twinning rate was still higher in fall-bred than in spring-bred cows (Gregory et al., 1990) because of a higher frequency of multiple ovulations. Embryonic survival decreased as age of cow increased beyond $5 \mathrm{yr}$.

The effects of year, interaction of year $x$ ovulation number and the quadratic regression on age of cow were significant for embryonic and fetal survival in the data set obtained by 
laparoscopy. The significant interaction of year $x$ ovulation number is due to greater survival of multiple than of single ovulations in 1985, whereas the reverse was observed in 1986. As observed in the data obtained by palpation, embryonic survival declined as age of cow exceeded 5 yr.

Even though the difference between single and multiple ovulations in embryonic and fetal survival was not statistically significant in either data set, there was a difference of .06 in favor of single ovulations. Even though small, this difference probably is real. However, the magnitude of this difference suggests that the primary constraint to achieving multiple births in cattle is ovulation rate and indicates that ovulation rate in puberal heifers should be a useful selection criterion for increasing twinning rate, assuming a high positive genetic correlation, which seems likely.

The right ovary was more active than the left ovary for both single and multiple ovulations. Even though the difference in embryonic and fetal survival between ovulations from the left and right ovaries was not statistically significant, embryonic survival of twins tended to be greater in the left uterine hom than in the right uterine horn. The frequency of unilateral multiple ovulations (right and left ovary combined) exceeded bilateral multiple ovulations, in agreement with the report of Morris and Day (1987). This phenomenon is of interest from an evolutionary standpoint as is the greater ovulatory activity of the right ovary. Because there is little or no migration of embryos between uterine horns in the bovine (Scanlon, 1972), the lack of a difference in embryonic survival between unilateral multiple ovulations involving either the left or the right ovary and bilateral multiple ovulations is of interest. Placenta(s) may attach in both uterine horns even though the embryo(s) may be positioned only in a single hom. A comparison of placental cotyledonary attachments between the gravid and nongravid uterine horn in cows with a unilateral twin pregnancy indicated a similar number of cotyledons in the two uterine horns (Scanlon, 1974). Thus, both uterine homs may provide matemal support to the embryo(s) even though the embryo(s) are located only in a single horn.

The incidences of embryonic survival (.62) and of twin births (.48) i.e., $.62 \times .77$ in cows with multiple ovulations (laparoscopic observation) are greater than reported previously for cows with double ovulations occurring naturally (Kidder et al., 1952; Labhsetwar et al., 1963; Morris and Day, 1987) or resulting from gonadotropin treatment (Gordon et al., 1962). Most of the cows included in the current study were crossbred. Cundiff et al. (1974) reported significant maternal heterotic effects on embryonic survival in crossbred cows expected to produce single ovulations.

An evaluation of ovulation rate and twinning rate in a herd of Holstein cows (Kidder et al., 1952) indicated that the frequency of twin ovulations $(13.1 \%)$ was significantly higher than the frequency of twin births (1.9\%). However, a subsequent reassessment of ovulation rate in the same herd reported the frequency of twin ovulations to be $5.4 \%$ (Labhsetwar et al., 1963). Morris and Day (1987) reported ovulation rate, determined by rectal palpation, and twinning rate to be 1.29 and 1.09 , respectively, suggesting that low embryonic survival was associated with multiple ovulations. Conception rate and twinning rate in gonadotropin-treated cows with double ovulations were 85.9 and $41.0 \%$, respectively (Gordon et al., 1962).

Discrepancies among studies on the relationship between ovulation rate and twinning rate in multiple-ovulating cows may be attributable to sampling error (i.e., small number of observations for twin ovulations and twin births) and(or) to low precision in the determination of ovulation rate by rectal palpation of the ovaries. The precision of rectal palpation was evaluated in our study (to be discussed) but was not evaluated in the other studies where ovulation rate was determined by palpation.

Embryonic and(or) fertility losses in cattle with a single ovulation range from .25 to .30 and have been categorized as either pre-d 16 (time of luteolysis in nonpregnant cows) or post-d 16 losses; pre-d 16 loss is about .20 and post-d 16 is .05 to .10 of the total matings (Ayalon, 1978; Hawk, 1979; Maurer and Chenault, 1983). Because fertilization rate in parous cows ovulating one oocyte approaches $100 \%$ (Maurer and Chenault, 1983), the .31 loss in conception rate for cows laparoscoped to have one ovulation was differentiated to be about .20 to d 16 of gestation (Maurer and Chenault, 1983) and about .11 from d 16 to parturition (or .14 based on embryos surviving to d 16). If twin embryos survive independently, the incidence of twin, single and no calves 
TABLE 6. DETERMINATION OF OVULATION RATE BY LAPAROSCOPY VERSUS OVARIAN PALPATION ${ }^{a}$

\begin{tabular}{llccc}
\hline \hline $\begin{array}{l}\text { Palpation } \\
\text { determination } \\
\text { (CL number) }\end{array}$ & \multicolumn{4}{c}{$\begin{array}{c}\text { Number of CL by } \\
\text { laparoscopy }\end{array}$} \\
\cline { 2 - 5 } & 1 & 2 & 3 & Total \\
\hline 1 & 147 & 38 & 2 & 187 \\
2 & $(89.6)^{\mathrm{b}}$ & & & 138 \\
3 & 17 & $\begin{array}{l}115 \\
(74.7)\end{array}$ & 6 & 13 \\
Total & 0 & 1 & 3 & 4 \\
\hline
\end{tabular}

a Number of corpora lutea (CL) on the left and right ovary (ovulation rate) was determined in the same cows by both rectal palpation and laparoscopic visualization of the ovaries 7 to 11 d postestrus.

Wumber of observations and percentage agreement between procedures in parenthesis. Mean for ovulation rate determined by laparoscopy vs palpation was 1.53 vs 1.44 , respectively.

for cows with two ovulation sites would be $.48, .42$ and .10 , respectively. The probability for twin, single or no calves is $p^{2}, 2 p q$ and $q^{2}$, respectively, where $\mathrm{p}=$ probability of survival and $q=1-p$. The experimental distribution within cows laparoscoped to have two ovulation sites was $.48, .29$ and .23 , respectively, or .13 fewer single births and .13 more nonpregnant cows. The overall pregnancy rate for multiple ovulating cows was .90 theoretically, and was .77 experimentally, thus suggesting that some embryonic losses for twin embryos are not independent. An evaluation of embryonic development at $52 \mathrm{~d}$ of gestation in cows with multiple fetuses revealed that multiple fetuses contained within the same placenta were either all alive or all dead (Echternkamp, 1987), suggesting that embryonic death after anastomosis of the two placentas resulted in death of both fetuses. Using the above estimates of embryonic mortality in cattle and assuming independent survival (stage 1) to d 20-25 (placental anastomosis) and dependent survival of twin embryos subsequently (stage 2), the theoretical distribution of twin, single and no calves would be $.49, .28$ and .23 , respectively, with an overall conception rate of .77 ; the probability for twin, single or nonpregnant is $p^{2} r^{2}, 2$ pqr and remainder, respectively, where $r=1$ - (stage 2 loss + stage 1 survival). The experimental distribution of $.48, .29$ and .23 , respectively, and .77 conception rate are similar and provide support for the two stages of survival (independent and dependent) for twin embryos. The calculated embryonic survival rates for stages 1 and 2 , with our experimental results, are .78 and .88 , respectively.

Precision of Ovulation Rate Determination by Ovarian Palpation. Comparison of ovulation rates obtained in the same cows by laparoscopic visualization and by rectal palpation of the left and right ovary are reported in Tables 6 and 7. All palpations for ovulation rate were done by one person. Palpation correctly identified 147 of 164 single ovulations $(89.6 \%) ; 115$ of 154 twin ovulations (74.7\%) and 3 of 11 triplet ovulations (27.3\%). Thus, overall precision for determination of ovulation rate in 329 postpartum cows by rectal palpation of the ovaries was $80.5 \%$. The major source of error $(64.1 \%)$ was failure by rectal palpation to detect a second corpus luteum on the same ovary or the contralateral

TABLE 7. COMPARISON OF OVULATION RATE DETERMINED BY LAPAROSCOPY WITH RECTAL PALPATION OF THE OVARIES ${ }^{\mathrm{a}}$

\begin{tabular}{|c|c|c|c|c|c|c|c|}
\hline \multirow{3}{*}{$\begin{array}{l}\text { Type of } \\
\text { ovulation } \\
\text { by palpation }\end{array}$} & \multirow[b]{3}{*}{ Ovary } & \multicolumn{5}{|c|}{ Type of ovulation by laparoscopy } & \multirow[b]{3}{*}{ Total } \\
\hline & & \multicolumn{2}{|c|}{ Single } & \multicolumn{3}{|c|}{ Multiple } & \\
\hline & & Left & Right & Left & Right & Bilateral & \\
\hline Single & $\begin{array}{l}\text { Left } \\
\text { Right }\end{array}$ & ${ }^{53}(81.5)^{b}$ & $\begin{array}{l}2 \\
90(90.9)\end{array}$ & $\begin{array}{r}10 \\
0\end{array}$ & $\begin{array}{r}0 \\
15\end{array}$ & $\begin{array}{l}8 \\
7\end{array}$ & $\begin{array}{r}73 \\
114\end{array}$ \\
\hline \multirow[t]{3}{*}{ Multiple } & Left & 10 & 0 & $20(62.5)$ & 0 & 1 & 31 \\
\hline & Right & 0 & 3 & 0 & $41(73.2)$ & 0 & 44 \\
\hline & Bilateral & 0 & 4 & 2 & 0 & $61(79.2)$ & 67 \\
\hline Total & & 65 & 99 & 32 & 56 & 77 & 329 \\
\hline
\end{tabular}

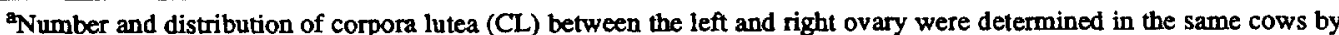
laparoscopic visualization and rectal palpation of the ovaries 7 to $11 \mathrm{~d}$ postestrus.

bumber of observations and percentage agreement between the two procedures. 
ovary. The second most frequent error (26.6\%) was mistaken identification of a follicle or corpus albican as a corpus luteum.

The net effect is that ovulation rate is underestimated by palpation, i.e., a higher percentage of those called singles are actually multiples (.21) than is observed for those called multiples that are actually singles (.12).

These values on precision of ovulation determination by palpation are on postpartum cows, and our primary interest in use of the procedure is to determine ovulation rate in puberal heifers. Because of the smaller size of the reproductive tract and easier accessibility to the ovaries, we believe that precision is greater in puberal heifers than in postpartum cows. Even if the precision of ovulation rate determination by palpation is not greater in heifers than in cows, we believe that the accuracy level observed in cows is sufficient to be useful in puberal heifers.

\section{Impllcations}

The potential of multiple observations of ovulation rate in puberal heifers was considered as an indirect selection criterion of twinning rate. The heritability $\left(h^{2}\right)$ of a single observation of ovulation rate was $.07 \pm .03$, whereas the $h^{2}$ of mean ovulation rate for an average of 7.9 estrous cycles was $.34 \pm .18$. Results suggest that permanent environmental effects on ovulation rate are not important. The effect of ovulation rate on embryonic survival was small $(P>.05)$ and did not differ between unilateral and bilateral multiple ovulations. Therefore, results suggest that multiple observations of ovulation rate in puberal heifers should permit effective indirect selection for twinning rate among yearling heifers based on individual performance and among young sires based on ovulation rate of sibs and daughters.

\section{Literature Cited}

Ayalon, N. 1978. A review of embryonic mortality in cattle. J. Reprod. Fertil. 54:483.

Cundiff, L. V., K. E. Gregory and R. M. Koch. 1974. Effects of heterosis on reproduction. J. Anim. Sci. 38:711.

Echlernkamp, S. E. 1987. Fetal development in cows with multiple fetuses. Theriogenology 27:226 (Abstr.).

Gordon, I., G. Williams and J. Edwards. 1962. The use of serum gonadotropins (P.M.S.) in the induction of twin pregnancy in the cow. J. Agric. Sci. (Camb.) 59:143.

Gregory, K. E., S. E. Echternkamp, G. E. Dickerson, L. V. Cundiff, R. M. Koch and L. D. Van Vleck. 1990. Twinning in cattle: 1 . Foundation animals and genetic and environmental effects on twinning rate. J. Anim. Sci. 68:1867.

Harvey, W. R. 1977. Users Guide for LSML 76. Mixed Model Least-Squares and Maximum Likelihood Computer Program. The Obio State Univ., Columbus.

Hawk, H. 1979. Infertility in dairy cattle. In: H. W. Hawk (Ed.) Beltsville Symposium in Agricultural Research (3). Animal Reproduction. pp 19-29. Allanheld, Osmon and Co., Montclair, NJ.

Kidder, H. E., G. R. Barrett and L. E. Casida. 1952. A study of ovulations in six families of Holstein-Freisians. $J$. Dairy Sci. 35:436.

Koch, R. M., K. E. Gregory, and L. V. Cundiff. 1974. Selection in beef cattle. II. Selection response. J. Anim. Sci. 39:459.

Labhsetwar, A. P., W. J. Tyler and L. E. Casida. 1963. Analysis of variation in some factors affecting multiple ovulations in Holstein cattle. J. Dairy Sci. 46:840.

Lush, J. L. 1945. Animal Breeding Plans. Iowa State Univ. Press, Ames. p 173.

Maurer, R. R. and J. R. Chenault. 1983. Fertilization failure and embryonic mortality in parous and nonparous beef cattle. J. Anim. Sci. 56:1186.

Morris, C. A. and A. M. Day. 1987. Ovulation and calving data in a twin breeding experiment. Proc. Aust. Soc. Reprod. Biol. 19:29.

Scanlon, P. F. 1972. Frequency of transuterine migration of embryos in ewes and cows. J. Anim. Sci. 34:791.

Scanlon, P. F. 1974. Cotyledonary attachments in uteri of pregnant cattle, sheep and white-tailed deer. Can. J. Anim. Sci. 54:259 (Abstr.). 